\section{Antiquity of Neolithic Man.}

The letter of Mr. J. Sinel, in Nature of September 19, on the submerged forest bed in Jersey, deals with several questions of great interest in relation to the submerged forest on the south-western coast of Wales. $I$ hope to publish shortly an account of this forest-bed (so far as it is seen in Pembrokeshire) and the deposits associated with it, but in the meantime I may state that I have found worked flints-flakes and coresin two localities on the Pembrokeshire coast in positions which correspond with that of the stratum of blue clay below the forest-bed at St. Heliers. These flints were clearly worked by men who inhabited the woodland, now submerged, before the trees fell into decay and formed the peaty mass of trunks, branches, leaves, \&c., overlying the true root-bed of the "submerged forest." One locality near Amroth, in Carmarthen Bay, yielded cores and flakes in abundance; the circumstances indicate the existence of a chippingfloor or implement-factory on this part of the submerged land-surface, which now, during spring tides, is covered by not less than $20 \mathrm{ft}$. of water. In the patch of submerged forest recently exposed at Freshwater West, in southern Pembrokeshire (see NaturE, March 28, 1912), a few small flint implements were also found.

Both at Amroth and Freshwater West the flints occurred below the peaty layer in a thin blue slime or clayey silt, which rests in turn upon clayey rubble largely composed of material derived from older superficial deposits. There is evidence that the forest trees in Pembrokeshire are rooted either in unquestionable glacial Boulder Clay or in a clayey drift allied to the glacial deposits. There appears, therefore, an interesting agreement in the character of the substratum of the submerged forest in Jersey and on the Pembrokeshire coast, and the agreement further extends to the composition of the peat. All the plants (with others) mentioned by $\mathrm{Mr}$. Sinel occur in the peat near Amroth and the remains of beetles are fairly common.

A point of difference, which may be more apparent than real, between the two localities, is the occurrence, according to Mr. Sinel, of blue "marine" clay below the peat at St. Heliers. In Pembrokeshire the blue slime, whence the flints were obtained, has yielded no evidence of marine origin; it appears rather to resemble an old marsh silt which developed into swampy soil, but it is quite possibly only the estuarine fringe of a marine clay which is now wholly submerged. The deposits, it may be, would be similar if compared at corresponding levels.

The geological horizon of the worked flints of the Pembrokeshire submerged land-surface appears identical with that of the Neolithic implements from St. Heliers. One of the most important questions that arises is whether these implements are so distinctivelv Neolithic in character as to exclude the possibility that they may belong to an earlier period. Two implements from the Pembrokeshire submerged forest were submitted to Mr. Reginald Smith, of the British Museum, but they were not found sufficiently characteristic in form to be dated according to modern detailed classifications of implements.

The term "Neolithic" is frequently applied to any surface finds of implements which are unabraded and not obviously of the familiar heavy Palæolithic forms. But while on the one hand many so-called "Neolithic" implements belong to the later prehistoric ages of Bronze and Iron, on the other hand some surface sites yield implements closely resembling Late Palæolithic types. This is so, for instance, in South Pembrokeshire, where recently I have obtained from several chipping-floors on the high ground bordering the coast a number of small implements, amongst NO. 2240 , VOL. 90] which Mr. Reginald Smith has recognised several scrapers, probably of Late Palæolithic (Aurignacian) types. But some of these early forms occur on sites which have yielded also typical Neolithic tools (with ground edges) and pottery, and, moreover, it is not yet possible to show that they are older than the submerged forest.

I join with Mr. Sinel in expressing the hope that other records of implements from the submerged forest may be obtained, but further I should like to suggest that it is of great importance that all finds should be compared with the series of implements in our national collections in order that their age may be definitely ascertained.

Giltar, Shooter's Hill, London.

A. L. LEACH.

\section{Human Jaw of Palseolithic Age from Kent's Cavern.}

Prof. A. KeITH, in discussing the paper read at Dundee by Prof. Boyd Dawkins for Dr. Duckworth on the fragment of a jaw of Palzolithic age from Kent's Cavern, is reported by The Times to have said that "the whole thing was ridiculous and was not even scientific, for the specimen had not been shown in the position in which it had been found."

The specimen in question is in the museum of the Torquay Natural History Society. Its position has been defined in the late Mr. W. Pengelly's reports to the British Association, and more particularly in his Cavern Note-book and Diary, which are at present, with all his other records of Kent's Cavern, in the possession of his elder daughter, Mrs. Louis Maxwell.

By the kindness of Mrs. Maxwell, I have had the opportunity of examining the diary, and have also had a look at the specimen now in its place in the museum. The actual record of the fragment is as follows:- "Thursday, January $3[1867]$. To the Cavern. The objects found to-day were as below:-

"No. 1930. In granular stalagmite. 7th Parallel, including part of a Human Jaw, a Flint Flake, a wellrolled Flint pebble from which a chip had been broken."

In the British Association's Third Cavern Report, 1867 , the further fact is stated, viz. that the object was found "about 30 feet from the Northern Entrance to the Cavern and deeply imbedded in Granular Stalag. mite 20 inches thick."

The position of the jaw in the cavern is thus ascertainable to a few feet, and its depth in the stalagmite to a few inches. But it tells its own tale. It is practically a specimen of the characteristic granular stalagmite, which seems to have been of Palæolithic age throughout. Pengelly mentions (Fifth Report) how cave bear, hyæna, and rhinoceros were met with not only in the granular stalagmitic floor, but quite at its upper surface (Trans. Devon Assoc., v., xvi., p. 250). Indeed, Pengelly records the occurrence of a tooth of rhinoceros found in another part of the cavern (No. 4090, found May 27, 1869), "which was not only in quite the upper part of the stalagmite, but instead of being completely covered, projected above its surface" (Trans Devon Assoc., vol. xvi., p. 207).

Having known Kent's Cavern long before the British Association exploration, and having been instructed therein by Mr. Pengelly for cave research elsewhere, I trust you will permit me to bear this testimony to the accuracy and detail of Pengelly's Kent's Cavern records.

I may mention that in 1884 Pengelly collected the whole of the sixteen Kent's Cavern reports in a single paper to the Devonshire Association. Not only is this paper much more convenient for reference than the reports scattered over sixteen years of the British Association, but occasional notes review the early 